\title{
The Effect of Manpower Planning and Development in Lagos State (Nigeria) Civil Service Performance
}

IGBOKWE-IBETO, C.J || OSAKEDE, K.0 || ANAZODO, R.0

\section{Abstract}

T he study examined effects of manpower planning and development in Lagos state civil service performance. Lagos state civil service is the greatest asset of the state in its quest for socio-economic development. The primary question that was explored is whether the nature of manpower planning and development curriculum in Lagos state civil service has effect on the service performance and the attainment of state objective. The study relied on primary and secondary data, and multiple stage sampling technique was used to select the sample population. The data collected was presented in frequency bar chart and simple percentage. Pearson's Product Moment Correlation Coefficient (PPMC) statistical tool was used to test the hypotheses. Findings of the study show that the nature of manpower planning and development curriculum has a positive effect on the Lagos state civil performance. It also reveals that the manpower planning and development has a positive effect on the attainment of Lagos state objective. To achieve better performance in the service, it should among others, improve on the current manpower planning strategy and continue to update its manpower development curriculum in line with the global best practices. Given the pivotal role that technology plays in the 21st century, the service should avail itself the windows of opportunities that information technology provides in its drive to enhance employees' skills, knowledge and abilities that will invariably improve the service performance. Yet, the service should imbibe the prescripts of New Public Management theory (NPM), and that goals and targets should be defined and measurable as indicators of organizational performance.

Keywords: Efficiency, Human Resource, Management, Planning, Service Delivery, Manpower, New Public Management, Lagos State, Nigeria. 
The Effect of Manpower Planning \& Development in Lagos State Civil Service Performance 77

\section{Introduction}

In the Western countries, manpower planning and development as a human resource management (HRM) practice has witnessed a paradigm shift from a micro-analytical approach to macro-strategic approach but in a developing country like Nigeria, micro level perspective is yet to be fully explored and analyzed. Beside the traditional personnel functions, HRM has recognized new roles in terms of employee champion, change agent and strategic partner (Ulrich, 2007).

The importance of obtaining manpower data and assessing the reliability of such data has become a salient issue to both practitioners and researchers. The question of how HRM policies and practices are linked to employee and organizational performance has been a subject of great interest to academics, practitioners and consultants (Wright, McMahan, McCormick \& Sherman, 1999).

Manpower planning and development as a function of management is highly indispensable in the achievement of organizational objectives. There is need to plan for the various resources such as human, material and time, etc, in order to achieve stated objectives. It should be noted that it is the function of the personnel to combine the various resources in an appropriate manner in order to actualize the objectives of the organization. In this globalized era, there are increasing claims that the route to competitive advantage is achieved through people. In a situation where identical nonpeople resources in the form of finance, raw materials, plants, technology, hardware and software are made available to competing organizations, the differences in economic performance between organizations can be attributed to differences in the performance of the organizations workforce. In other words, the calibre of the human resources in an organization determine the success or failure of an organization, hence, justify the rationale to plan for, and develop the personnel in various units of the organization in order to achieve the stated goals.

According to Ake (2001), the development of indigenous manpower to serve as the propelling force for national growth and development is no doubt a key to Nigeria's socio-economic and political development. This is quite indispensable considering the argument of the concept of transfer of technology as a propelling force for the development of the developing countries of which Nigeria is one (Ake 2001). However, it is important to state that the lack of adequate emphasis on manpower planning and development as a tool for development in Nigeria on the part of government as well as 
the organized private sector could not be far-fetched from the lack of understanding of both the concept and methods for manpower planning and development in a postcolonial Nigerian State in which the process of manpower planning and development for national growth was distorted by colonialism with it attendant negative orientation that was injected into political leadership (Ekpo 2009). Thus, manpower planning and development became an elitist design that was geared to favour capitalist mode of production in which labour was relegated to the background among the factors of production (Omodia, 2009:113).

Basically, manpower planning and development involves applying the planning process to human resources in the organization. The need to invest massively in manpower planning and development in recent time cannot be over emphasized if the achievement of organizational objectives is to be realized. No wonder, Armstrong (2010) argues that the role of human resource planning and development in the achievement of organizational objectives is an art and science in its own right.

With the influx of multinational companies into the country, particularly under the umbrella of neo-liberal market reform, Nigeria has witnessed an inspiring mix of domestic and foreign companies. The growing competition in a large market with an estimated population of 167 million (NPC, 2013) has made both domestic and foreign companies intensely productive sensible. This, in turn, has generated a strong interest and enthusiasm among organizations, particularly in the public sector, to vigorously search for the best management practices in all fields of HRM to improve their overall performance. Thus, Lagos State civil service offers an appropriate framework to examine how a basic HR practice such as manpower and development, that has received considerable attention in Western countries could serve as a useful HR planning tool, will affect organization performance in a developing country like Nigeria.

It may be asked why manpower planning and development deserves special attention instead of emphasizing the conventional and popularly known pathologies of the Nigerian public sector such as: inefficiency, accountability, status conflict between technical professionals and generalist administrators, nepotism, corruption, physical conditions of work among others. It would seem that manpower planning and development is so important to HR functions, especially in evaluating the link between it and organizational performance and how well they fit together is important. Yet, any 
The Effect of Manpower Planning \& Development in Lagos State Civil Service Performance 79

attempt to construct a virile civil service without a clear articulation of the manpower planning and development may not yield the desired result.

The Lagos state civil service comprises the entire ministries, departments and agencies through which government carry out its policy objectives into practical results that would benefit the citizenry. Therefore, the right number and quality of personnel should be in place to perform its varied functions. Performance and employees' commitment to duties in the civil service has been a subject of controversy and debate by all and sundry. Inefficiency, ineffectiveness and poor service delivery are all common features of the service. It is along this line of thought that Igbokwe-Ibeto (2012:57) after examining manpower planning and development and the attitude to work of Nigerian civil servants concluded that "Nigeria's ambition for rapid industrialization, economic prosperity, and socio-political stability will singularly and collectively be frustrated if the current manpower planning and development and poor work attitude of civil servants is not urgently and positively improved."

Macro and micro manpower planning and development as an important HR strategy for achieving national and organizational performance is hardly taken serious by the Nigerian public sector. In fact, public sectors managers see manpower planning and development as a ritual and an academic exercise. In spite training and development institutions such as Administrative and Staff College of Nigeria (ASCON), Centre for management and Development (CMD), National Institute for Policy and Strategic Studies (NIPSS) among others, it appears manpower planning and development has made little impact on civil service performance. Igbokwe-Ibeto \& Osawe (2014:18), Eneanya (2009:21) and Adamolekun (2002) traced this ugly situation to issues such as: training based on bureaucratic politics and patronage, predominance of foreign oriented training and development, alter neglect of local problem realities and issues when planning and designing curriculum and models based on borrowed models that are rarely updated, use of irrelevant manpower planning and development curriculum that have no bearing with national/state objectives and policy. A number of studies such as Omodia (2009:113), Oguniyi (1992:122) have been carried out and solutions have been suggested, but the problem remained endemic and persistent in the civil service. This empirical study therefore, seeks to examine the effect of manpower planning and development in Lagos state civil service performance. 
The main objective of this study is to examine the effect of manpower planning and development in the Lagos state civil service performance. The specific objectives include:

1) To examine the nature of manpower planning and development curriculum in the Lagos state civil service as regards organizational performance.

2) To examine the effect of manpower planning and development in the attainment of Lagos state objective.

3) To identify the challenges facing manpower planning and development in the Lagos state civil service and proffer solutions.

To investigate effects of manpower planning and development in the Lagos state civil service in this study, the following research questions will serve as a guide.

1) What is the nature of manpower planning and development curriculum in Lagos state civil service as regards organizational performance?

2) What is the effect of manpower planning and development in the attainment of Lagos state objective?

This study is geared towards testing the following two research hypotheses for the purpose of this study.

1. $\boldsymbol{H}_{0}$ : The nature of manpower planning and development curriculum in Lagos state civil service has a negative effect on organizational performance.

$\boldsymbol{H}_{1}$ : The nature of manpower planning and development curriculum in Lagos state civil service has a positive effect on organizational performance.

2. $\boldsymbol{H}_{0}$ : Manpower planning and development in the Lagos state civil service has a negative effect on the attainment of Lagos state objective.

$\boldsymbol{H}_{1}$ : Manpower planning and development in Lagos state civil service has a positive effect on the attainment of Lagos state objective.

This study will enable public organizations to reassess the design and evaluation of manpower planning and development practice with intentions of sustaining effective personnel utilization towards efficient service delivery. It is also intended to serve as a 
The Effect of Manpower Planning \& Development in Lagos State Civil Service Performance 81

guide to HR practitioners to identify their possible shortcomings in manpower planning and development and undertake corrective measures. Faced with stiff poor performance, public organizations cannot afford to lose relevance in the light of the ongoing transformation and change agenda of the federal and Lagos State Government, hence the need for proactive manpower planning and development schemes in the civil service organizations that encourage effective and efficient utilization of personnel for optimum performance.

\section{Conceptual Discourse}

Some concepts in social and management sciences do not easily lend themselves to universally agreed definitions. This makes every definition perhaps only relevant within the parameters set for a given investigation. This is the intent of Babbie \& Mouton (2001) methodological research diction that "we specify why we use particular terms for the purpose of facilitating their contextual discourse and comprehension."

The conceptual framework of this paper is geared towards having a proper understanding of the concept of manpower planning and development and how it relates to the concept development of manpower. Although both concepts could be used interchangeably, it is important to accentuate that the concept of manpower planning evokes several meanings and studies elaborating different dimension of it abound. Ibijofo in (Obojo, 2012) conceived manpower planning as "the process by which an organization ensures that it has the right number of people and the right kind of people at the right place and the right time, doing things for which they are economically most useful." The concept of manpower development could be defined as "the existence of unskilled and/or skilled humans that need training or re-training to perform specific task in society" (Ekpo, 2009). Thus, manpower development could be seen as organizational specific. This is because it is largely a function of organizational manpower or job specification. That is, it could be viewed as the adaptation of the human resources available in the country to the needs, objectives and orientation of a given organization.

Conversely, the concept development of manpower could be viewed as a concept which is generic because of its focus on turning out human resource that is needed for the development of the State (Drucker, 1999). As a result, development of manpower views man as the most important asset in the society (Chalofsky \& Reinhart, 2008; 
Muchinsky, 2000; Drucker, 1999; Ekpo, 1989). A typical example of the manifestation of this concept could be viewed from the perspective of the Nigerian educational system which is anchored on the 6-3-3-4 system which sought to address the manpower needs of the country through mechanisms geared towards developing manpower that would boost the nation's socio-economic and technological advancement (FGN, 1998).

However, as earlier stated, both concepts could be used interchangeably in that they are both encompassing of each other. For instance, the 6-3-3-4 educational policy in Nigeria which was classified as most compatible is a typical example of the 'concept development of manpower' in the sense that the mechanism involves turning out human resources that would serve as inputs to industries. It is also imperative to emphasize that unbundling the system into parts, indicate that the parts $6,3,3$, and 4 could be viewed as 'manpower development' because it involve the process of training manpower for meeting specific sectoral needs (Omodia, 2009). Manpower training according to Adeleke in (Igbokwe-Ibeto \& Osawe, 2014:19) is the means and process of imparting special skills which equip individual to perform specific jobs. Yet, for sustainable manpower development, there is need for human capacity building.

Capacity building is a process of change and the systematic management of transformation. It involves the transformation of peoples, institutional and society's capacity (World Bank, 2012). According to Dibie \& Dibie (2014), capacity building in the context of sustainable manpower development implies a dynamic process which enables individuals and agencies to develop the critical social and technical capacities to identify and analyze problems as well as provide solutions to them.

Civil service as an organization is the centre of Public Administration structure. It is the major instrument through which government; be it federal, state or local manage development (Olu-Adeyemi, 2009:390). It should be noted however that the effect of public service bind on all the entire citizenry, as they render direct service to all and sundry, as opposed to the private sector that render services to only a few individual.

Civil service performance simply is the extent to which an individual, unit or department carryout task assigned to him or it. It is also a means by which an organization evaluate an individual employee or unit input and out level especially in the area of attaining set goals or task assigned to him or it. In the view of Byars \& Rue (2006) performance is the degree to which an employee accomplished the tasks that made his or her job. However, the researchers' working definition for purpose of this 
The Effect of Manpower Planning \& Development in Lagos State Civil Service Performance 83

study is achievement of targets (service delivery) of the tasks assigned to organizations or employees' within particular period of time. It involves the execution of duties and responsibilities assigned by constituted authorities which one have promised to do, so as to achieve set goals.

\section{Theoretical Underpinning}

In social and management sciences, no one theoretical approach can adequately explain a social phenomenon. Nonetheless, we need a platform on which to investigate our subject of analysis. For this purpose and bearing in mind the constraints before us, we find New Public Management (NPM) theory relevant to anchor our discourse in this study. NPM was formally conceptualized by Hood (1991). New Public Management points to the failures and inadequacies of public sector performance over time and the problems lying squarely in the nature and processes of public sector activity and traditional public administration. As a new paradigm in public administration, New Public Management theory is the transition from old traditional public administration theories to an arrangement that is workable, practicable and result oriented. It places emphasis on efficiency, effectiveness, corporate governance, technological innovation and democratization. New Public Management theory is a relentless effort in the direction of greater cost reduction, transparency and accountability in resource allocation and performance management through the quality of service (Pollit, 1996).

New Public management theory therefore, captures the basis of institutional and organization restructuring as an attempt to raise its performance by improving the quality of service delivery. It is result focused rather than the process of result. Public management theory came up with different concepts for performance and principles to achieve it (Hood, 1991). Consequently, Hood identified the principles as 'accountability and efficiency; reduction of public sector expenditure; improvement in resource use through labour discipline; flexibility in decision making; competition in the public sector through decentralization and emphasis on result and not procedure.

The main thrust of New Public Management theory is not with what to do but how to do it better. The basic hypothesis hold that market oriented management of the public sector will lead to greater cost-efficiency and effectiveness for governments without having negative side-effects on other objectives and considerations. 
However, all theories are born refuted, New Public Management theory not an exception. The exponents fail to recognize that the ecology of public administration varies and that culture of any given society can hinder or accelerate its growth and development. For example, in Nigeria, because government is the largest employer of labour, even where and when there is no need for recruitment, government could embark on recruitment just to score cheap political support.

Despite the pit falls of NPM, the summary of the various views taken together, isolate New Public Management (NPM) theory as relevant and applicable in analyzing the subject matter of manpower planning and development because whenever issues of public sector efficiency and effectiveness is mentioned in contemporary times, NPM theory comes to mind. Thus, the elements of manpower planning and development based on this theory enable us have the bases for accessing the Lagos State Civil Service as regards manpower planning and development practices in the civil service.

The theory as relating to manpower planning and development also enables us direct our search light for possible causes of poor performance and low productivity in the Nigerian public sector. This theory is relevant and applicable to the study based on the fact that the input (quantity and quality of applicants) determines the output (performance). Efforts at conceptualizing the various steps help us have an insight into the effect of human resources management practices in an organization and its positive implication on organizational efficiency and employee performance which is the central theme of this study.

\section{The Interface between Manpower Planning and Development}

The nexus between manpower planning and development cannot be overemphasized. Economically, the relevance of manpower planning and development in Nigeria could be situated vis-à-vis economic development. This is because manpower planning and development captures the actual meaning of development, in that, it is people cantered or oriented (World Bank 2009; Grawboski \& Shields 2006). Indeed, the Gross National Development (GND) and the Gross Domestic Product (GDP) of a nation are also a function of the available manpower to man the economic development of such a nation. Any effort at improving the quality and growth of human resources can be seen as a means of sustainable development (Armstrong, 2010). This view was vividly captured by Omotade (1992:115) who argue that human resources constitute the ultimate dignity of 
a nation. After all, it is the interactions of people with natural resources that constitute development.

Bearing in mind that organization is not the building or equipment, it is the personnel that make up the organization, therefore, there is need to plan for, and develop the right quality and quantity of personnel that will take an organization to its peak. In essence, there is need to plan for and develop effective and efficient personnel that will handle both operating and managerial functions to achieve the objectives of the organization effectively and economically. Yet, for any organization to achieve a reasonable degree of success, it must not be plagued with excess or inadequate manpower. Here lies the importance of manpower planning. Excess or stock-pile employees can pose a serious problem for organizations. For instance, it can become a serious drain on profit.

In addition, manpower planning and development involves capacity building as well as harnessing a nation's or state's human capital which constitutes a sine-qua-non for national development. The umbilical relationship between manpower planning and development is clear. The former forecast demand for, and analyzes the supply of the right skills, professions, qualities, quantities and effectiveness while the later draws on these projections in estimating training and development needs of manpower for approved programmes. One major point that comes out forcefully from this nexus is that, it is through manpower planning that personnel management functions are actualized. For example, training and development programmes cannot be positively and successfully undertaken if the manpower forecasts are faulty or deficient.

Yet, the interface between manpower planning and development can manifest in political stability in the country or state. Arguably, a country that fails to adequately develop and harness her manpower would be doing so at the expense of her socioeconomic and political stability. It is along this line of thought that Omodia (2004) stressed the dysfunctional use of the nation's human resource among the youths in propelling political instability. According to Omodia (2004):

There has been a situation in which the Nigerian youth especially, those of poor family background were used as tools for disrupting the political democratic system through rigging, thugery and ethnic conflicts. These factors of rigging, thugery in addition to economic mismanagement, 
personal ambition or selfishness among others, were the factors that terminated the First and Second Republic.

Thus, manpower development could help the youths in the development of self and in improving the quality of their political participation. It has been argued that effective poverty alleviation scheme must involve manpower planning, development and utilization of local resource including human for solving local problems (Omodia 2005; Robb, 2000). Thus, manpower development is central to solving the present problem of poverty in Nigeria. Therefore, manpower planners should as a matter of necessity find out what the manpower scene is expected to be during the planned period. Lending support to this, Ebegbuna (1992) admonished that it will be a fruitless effort and exercise designing a project that will require a given number of experts without the prospects of having the required manpower in the right numbers at the right time.

Besides, a lot of data required for forecasting accurate training and development are generated through the Personnel Information System (PIS) because according to Ebegbuna (1992), personnel department is the midwife and mother figure of any organization. Through manpower planning, organizations ensure that the right calibre of persons are attracted, and these it nurtures to maturity through manpower planning, training and development.

Yet, the interface between manpower planning and development can be viewed and analyzed from many angles. For instance, the higher the quality of manpower in a country, the greater the advantage the country has over socio-economic and technological development. According to Ogunniyi (1992:123), the Cold War between the US and the former USSR is pure and simple, a display of qualitative manpower by both countries, each demonstrating her superiority in advancing technological and scientific pre-eminence to space and nuclear rivalry. A nation or state with inadequate manpower plan and development strategy will remain a poor and underdeveloped country or society so long as it remains a nation of illiterates and intellectual dwarfs; that is people with no saleable skills and competence to explore and exploit the untapped natural resources at her disposal. 
The Effect of Manpower Planning \& Development in Lagos State Civil Service Performance 87

\section{Steps in Short and Long Term Manpower Planning in Organizations}

Planning can either be short term or long term, based on the objectives of the (organization) planners. Boxall \& Purcell (2003) argue that it is vital to accept that change is inevitable and that some preparation for the future is therefore crucial. They further suggest that short-term planning is necessary for survival but long-term planning is a good thing in as much as it does not make the organization inflexible. Schular (1998) makes a similar point suggesting that planning will become more tentative and short term to deal with the rapidly changing environment but long-term needs are still important because some changes take place.

Short term manpower planning is the process of planning for human resources or personnel requirement in an organization within a period less than two (2) years. It is the requirements for specific skills or positions, which need to be filled in the context of existing plan; the period of such planning and execution according Cole (2002) ranges from one month to 18 months. Long term manpower planning involves planning for human resources requirement in an organization that involves more than 3 years. Alongterm view of manpower planning is essential for ensuring that the organization is supplied with skills which take time to be developed in most professional jobs, for example, require a training period of 3 to $5 y e a r s$ before the trainee can claim even the basic competencies of the profession. If an organization, decides to develop its own staff, it needs to look ahead for at least 5years from the time the first recruit was appointed. If the organization decides it will not train its own specialist but buy them from the labour market place, then it has to be reasonably assured of the availability of trained people in the labour market at the time they will be required. There are five major steps in both short and long term manpower planning which can be seen as follows:

\section{Step I}

Defining corporate objectives of the organization: Although the objectives of setting up public sector organizations vary but the most prominent objective is service delivery. Corporate objectives will indicate the ends towards which management will direct its effort. That is, it answers the question where does the organization want to be. For example, does the objective of the organization incorporate more staff in the next 12 months? This question has to be answered in planning for the organization personnel. 


\section{Step II}

Assessment of manpower requirement and demands: This involves the determination of the types of skills required in each department, section or unit of the organization after which comes recruitment of the right quality and quantity of workforce for the organization. In short term planning, management must consider how to recruit various candidates that will pass through the process of selection in order to match employees' with the current available jobs.

\section{Step III}

Assessment of manpower supply: This involves forecasting future human resources needs. Issues to be address here are: what category of staff do we have? What are the numbers in each category? What are the age and sex distribution within the category? How many staffs are suitable for promotion and redeployment? What is the age turn over? What are the potentials of existing staff in or to undertake roles in the organization? What is the overall employment likely to be in the cause of say five (5) years? What competition of manpower is likely?

\section{Step IV}

Determination of net human resources requirement: This is the differences between the total demand of human resources and internally available manpower. At the end of the exercise, if there is deficit in the amount of the manpower need, additional qualified people may be employed to fill the shortages. Here comes the question, how do we recruit? Is it by traineeship and apprenticeship or by the recruiting trained and experienced people? What is the provision for recruitment? Do we recruit part-time workers or not? On the other hand, if there is surplus manpower, the organization may be compelled to retrench some employees who may be redundant. Alternatively, the organization may embark on internal transfer and redeployment of employees.

\section{Step V}

Evaluating manpower plan or budget and monitoring of human resources programme: This the stage of setting manpower and monitoring of manpower 
The Effect of Manpower Planning \& Development in Lagos State Civil Service Performance 89

plan to ensure that target commensurate with actual performance and making necessary adjustment to deviation of plan.

\section{Step VI}

Training and development: What training programmes should be given to the new and existing staff? Should we concentrate on in-house or in-service training or should we send people on external courses? How do we develop the skills of the new and existing staff in order to promote service delivery?

There are variables to be considered in both short and long term manpower planning. These include: budgets constraints and allocation. The budget allocation specifically for the purpose of new employees will determine the number of new employees that can be hired; anticipated turn over in personnel due to retirement, death, transfer, promotion and termination of service; level of technology; technological changes; growth of the organization; knowledge of present manpower resources; training and development; social changes; economic changes; political factors and government policy, etc.

\section{Methods of Manpower Training and Development in Organizations}

The tools and methods for manpower development in organizations differs, and it is largely determined by the objectives of organizations, the idiosyncrasy of management staff or the chief executive, the organizational policy, as well as the organizational environment to mention a few. Thus, it is a common feature to see methods for manpower development varying from one organization to the other, just as a given organization can be tailored at adopting different methods at different times or a combination of techniques at the same time. However, three basic techniques of manpower training and development have been identified. They include:

(1) On the job method of manpower training and development: This method is basically different from the induction method in that induction is at the point of entry into the organization, while on the job method is a process through which knowledge and experience are acquired over a period of time, either formally or informally. This method involves the following: 
a) Orientation: This method of manpower development could be said to be an integral part of the recruitment exercise in that once an applicant has been found employable, it is expected that such an employee need to be positively oriented in line with the vision and objectives of the organization for effective discharge of function. In addition, since employee's function in an organization is basically affected by his perception of the organization vis-à-vis the rules and principles that exist in the organization, it therefore follow that an employee undergoes formal and informal orientation in a place of work. While the formal orientation focuses on job specification and occupational demands placed on the employee, the informal orientation involves the social interactions that take place in the place of work which could either boost performance or be detrimental to it (Koontz, Donnel, \& Weihrich, 2008). Therefore, orientation as a method of manpower development is quite indispensable because it helps in boosting the performance of employees' which is needed for competitive advantage in the global market.

b) Coaching: This is a method of on the job training and development in which a young employee is attached to a senior employee with the purpose of acquiring knowledge and experience needed for the performance of tasks (Igbokwe-Ibeto \& Osawe, 2014:24; Yalokwu, 2000).

c) Job rotation: This method involves the movement of an employee from one official assignment or department to the other, in order for the employee to be acquainted with the different aspects of the work process or through job enlargement. That is given additional responsibility to an employee who has been uplifted as a result of the acquisition of additional skill or knowledge (Lawal, 2006; Yalokwu, 2000).

d) In house training and development: This involve a formal method of on the job training in which skills and knowledge are acquired by employees through internally organized seminars and workshops 
geared toward updating the workers with new techniques or skills associated with the performance of their jobs (Igbokwe-Ibeto \& Osawe, 2014:24; Lawal, 2006).

e) Apprenticeship method: This method of manpower development involves the acquisition of skill through extensive practice for over a period of time by the trainee. This type of manpower development device could either be formal or informal. In the informal environments, the trainee is attached to the trainer, and he/she is expected to pay for an agreed period of apprenticeship (Nongo, 2005). In the formal environment, on the other hand, an employee of an organization could be placed under apprenticeship in the organization with pay.

(2) Off the job technique of training and development: This method of training and development takes place outside the actual job environment, e.g., training centres, training institutes, management development centres, etc. These techniques include the following:

a) In-service training and development technique: This method involves training outside the organization or workplace in higher institution of learning or vocational centres under the sponsorship of the organization or on terms that may be agreed upon between the organization and the worker (Lawal, 2006).

b) Committee/work discussion group method: This method according to Igbokwe-Ibeto \& Osawe (2014:25) entails manpower development through the involvement of employees in meetings, conference, committees and work group discussion geared towards injecting inputs in form of decision making as regard solving organizational problem. In this approach, individuals with common interest are brought together to discuss and attempt to solve problems. A group leader is appointed to supervise and keep the discussion on course to ensure that the group does not deviate from the subject. The main focus of this method of training and development is to provide the participants an environment in which they solve problems which are occurring in their day to day activity. This method is quite indispensable, especially in the 
aspect of training employees for managerial functions or heading organizational units or departments.

c) Vestibule training and development method: This is a method of manpower development through the acquisition of skills in a related working environment (Igbokwe-Ibeto \& Osawe, 2014:26). Under this method the trainee practices his skill with identical equipment that he uses or he is expected to use in his actual place of work (Nongo, 2005). This method is most suitable for sensitive operations where maximal perfection is expected. The purpose is therefore to enable perfection at work place.

(3) Simulation or management development method: Simulation is carefully developed exercise modelled on realistic situation in which trainees participate and receive feed backs. Management development technique is mainly for organizational managers. They are also useful for jobs in which the risk and cost of mistakes are high, e.g., pilot training. The techniques include the following:

a) In-basket training and development method: This is also called intrail approach. Under this method, participants are given a number of business papers such as reports, telephone messages, and memoranda that will typically come across a manager's desk or table. The papers presented in no particular order for actions, ranging from urgent to runtime handling. Each particular matter has to be first prioritized before action is taken on the information contained in the paper (Walker, 2007).

b) Case study analysis method: Here participants or trainees are given a simulated business problem. He or she is expected to study the information that is given in the case and make decisions based upon the situation (Walker, 2007).

c) Role playing: Role playing is used in teaching interpersonal skills such as managerial or sales interaction. Trainees adopt relevant roles, e.g., the role of manager and staff member; it can also be customer-client relationship (Igbokwe-Ibeto \& Osawe, 2014:26). 
The Effect of Manpower Planning \& Development in Lagos State Civil Service Performance 93

\section{Methodology}

In order to investigate manpower planning and development in Lagos state civil service, this study employed the descriptive survey method, with the researchers setting out to illustrate the association that exists among the dependent and independent variables. The researchers' main goal in a descriptive study is to describe accurately the relationship between two phenomena (manpower planning and development as regards organizational performance). This method is useful because the study is interested in finding the nature and to obtain an understanding of the issue under investigation. The study relied heavily on primary and secondary data. To supplement the data from primary source, secondary materials were sourced from academic literature on the subject matter. In this regard, questionnaire were used as instrument for collecting primary data, closed ended questionnaires to be precise, where questions were structured in line with the research questions and hypotheses using Liker three point rating scale questionnaire: Agree; Undecided; and Disagree.

The population was constituted of the officials from all 53 ministries, extra-ministerial departments, agencies and commissions (MDAs) in Lagos state with an estimated 119, 347 staff strength. However, since the study cannot cover the entire population within limit, the researchers had to select three ministries with total staff strength of 1,864 through the principle of randomization to constitute the study population. The ratio 1:7 was used to reduce the ministries to three and the decision to limit the study to three ministries was based on the need to have a manageable sample. This is in line with the law of small and large numbers as noted by Best \& Khan (2006), a sample equal or above 10 percent is valid to generalize results for the whole population. Thus, it was deemed a representative sample with regards to the research purpose and considering the fact that the problem under investigation appears or manifests the same way in all the ministries. Therefore, the findings can be used to make inferential judgment on the entire civil service.

Given the population of about 1,864 civil servants from the three ministries chosen for this study, the sample size using Taro Yamane's (1967) formula for sample size determination was used. Thus, the formula is given as:

$$
\begin{aligned}
& \mathrm{n}=\mathrm{N} \\
& 1+\mathrm{N}(\mathrm{e})^{2} \\
& \text { Where } \mathrm{n}=\text { sample size } \\
& \mathrm{N}=\text { Population of the study }
\end{aligned}
$$


$\mathrm{e}=$ Sampling error (in this case 5percent)

The sample size is therefore $n=329$

Having determined the sample size, the researchers proceeded by sharing the obtained data between the selected ministries. Based on this, the Rangan Kamaisan proportional allocation or distribution method was adopted to allocate the questionnaires to the ministries. This was to ensure that none of the surveyed ministries is cheated. The formula is given thus:

$$
\begin{array}{ll}
\mathrm{ns} & =\mathrm{Np} \times \mathrm{n} \\
\mathrm{n} & \\
\mathrm{ns} & =\text { Sample size allocation } \\
\mathrm{Np} & =\text { Population size } \\
\mathrm{n} & =\text { Total sample size } \\
\mathrm{N} & =\text { Total population size }
\end{array}
$$

A number of structured/close-ended questionnaires were self-administered to all categories of respondents, namely, senior and junior staff in the ministries who participated in the study with the help of two junior officers in each ministry. Three hundred and twenty-nine (329) questionnaires were administered to the sample population. Out of the 329 distributed questionnaires, the researcher was able to achieve questionnaire return of 300 usable or valid responses while 20 were not returned and 9 not properly filled out of the total distributed, yielding a response rate of 91.2 percent. The researcher proceeded with the analysis of the data as 91.2 percent response rate is regarded as very satisfactory for this study. Some rules of thumb about the response rate is that a response rate of 50 percent is adequate for analysis and reporting, 60 percent is good while 70 percent is very good (Babbie \& Mouton, 2001).

The study adopted the bar chart and simple percentage statistical method of analyzing the responses. Consequently, in order to test the hypotheses and establish the degree of association of the variables under consideration, the Pearson's Product Moment Correlation Coefficient (PPMC) statistical tool was used for this study. The results of the returned questionnaires were captured on Microsoft Excel for analysis and interpretation. The results were later used to draw deductions and conclusions on the 
subject matter of study in the concluding section. The statistical formula for the correlation is given below:

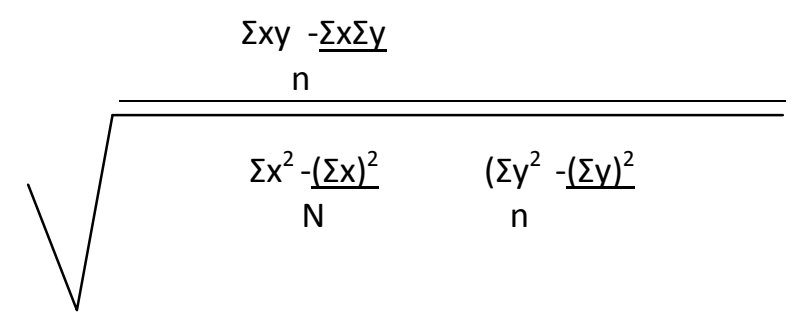

Where:

$\mathrm{n}=$ the total no of the data, $(\Sigma \mathrm{x})=$ sum of independent variable (population)

$(\Sigma y)=$ sum of the dependent variable, $(\Sigma x y)=$ sum of the product of $x$ and $y$

$\left(\Sigma x^{2)}=\right.$ sum of the squares of $x_{1}(\Sigma x)^{2}=$ square of the sum of $x_{1}\left(\Sigma y^{2)}=\right.$ sum of the squares of $y$

\section{Data Analysis}

This section is divided, i.e., the socio-demographical data of the respondents and the research questions based on the research objective totalling thirteen (13) questions in all.

Bar Chart 1: Respondents' Length of Service

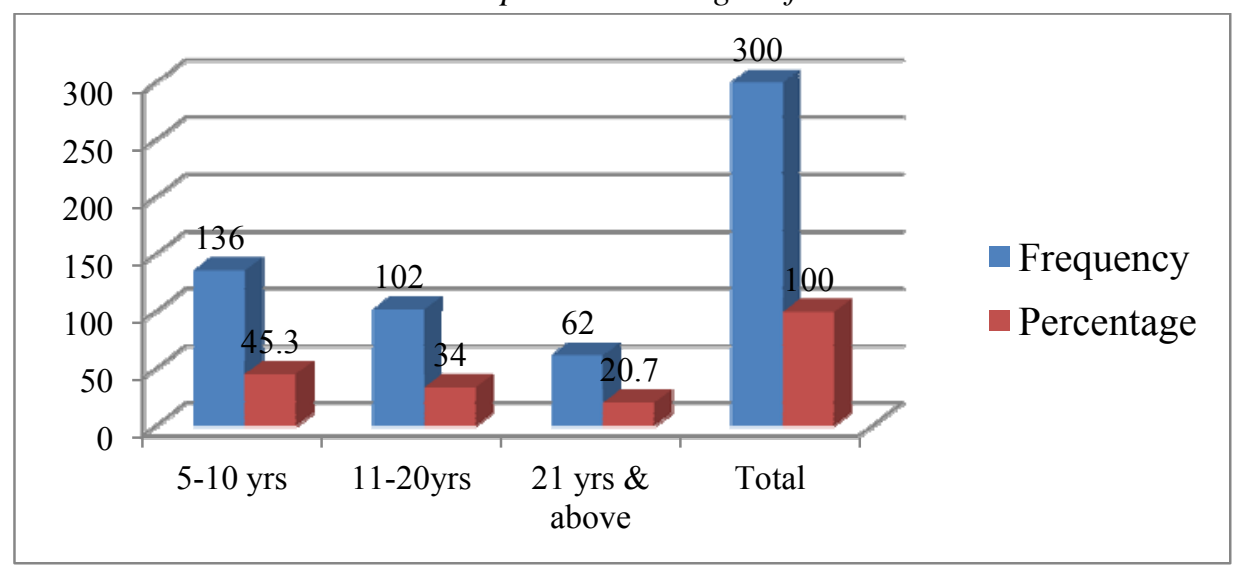

Source: Field Survey May, 2015 
Bar chart 1 on length of service shows that 136 or 45.3 percent had put in between 5-10 years in the service; 102 or 34.0 percent had put in between 11-20 years while 62 or 20.7 percent had served for between 21 years and above. This shows that majority of the surveyed workforce has put in between 5-20 years of service, the implication is that majority of them still have more years before retiring because of the present policy which sets retirement age for civil servants at 35 years of service or 60 years of chronological age whichever comes first. The essence of securing information on the respondents' length of service was to be sure that they relatively have undergone one form of training and development and understood what the survey was about and thereby, to some extent, be able to contribute to the issues under investigation.

Bar Chart 2: Respondents' Official Status

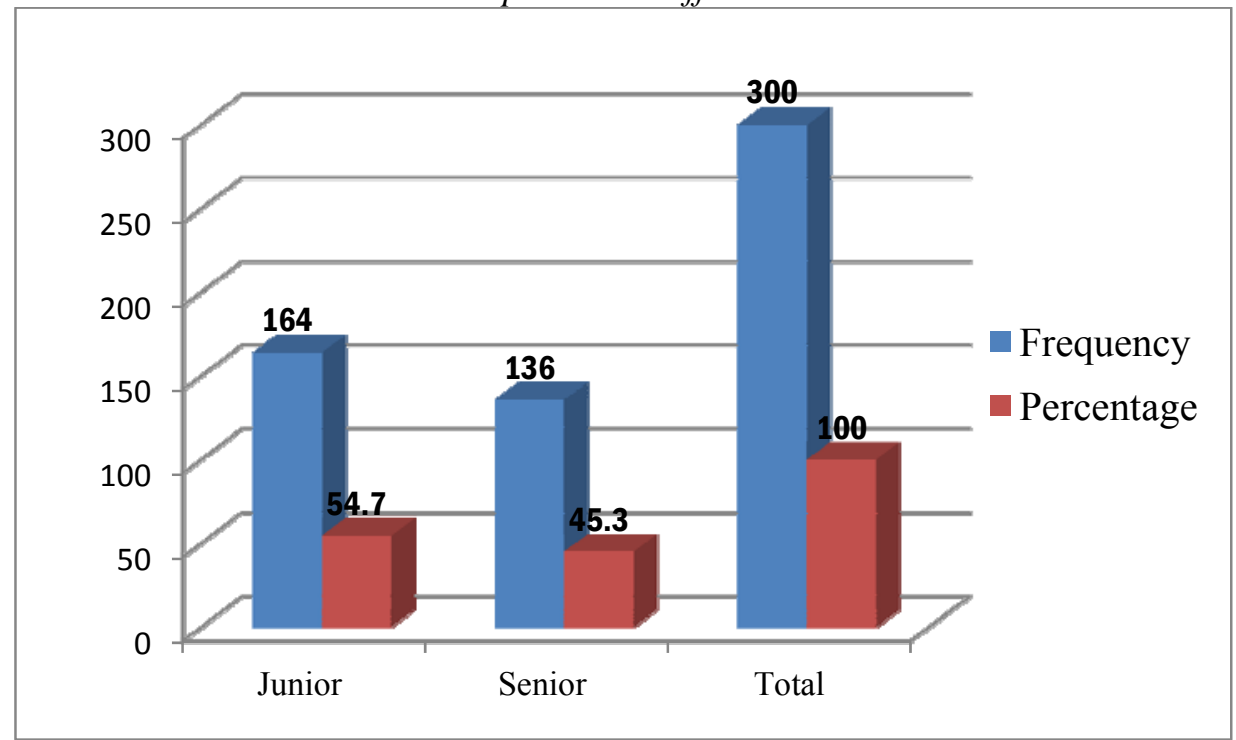

Source: Field Survey May, 2015

The above bar chart 2 on official status of respondents indicates that 164 or 54.7 percent were junior staff while 136 or 45.3 percent were senior staff. This shows that all categories of staff were captured by the survey. However, junior staff were more than the senior staff in the polled respondents. The merit of the application of this survey instrument is that, the spread of the questionnaire across the identified official status 
enabled the study to determine the level of consciousness and awareness of respondents on the link between manpower planning, manpower development and organizational efficiency.

Bar Chart 3: Respondents' opinion on whether there is need for manpower planning and development in an organization

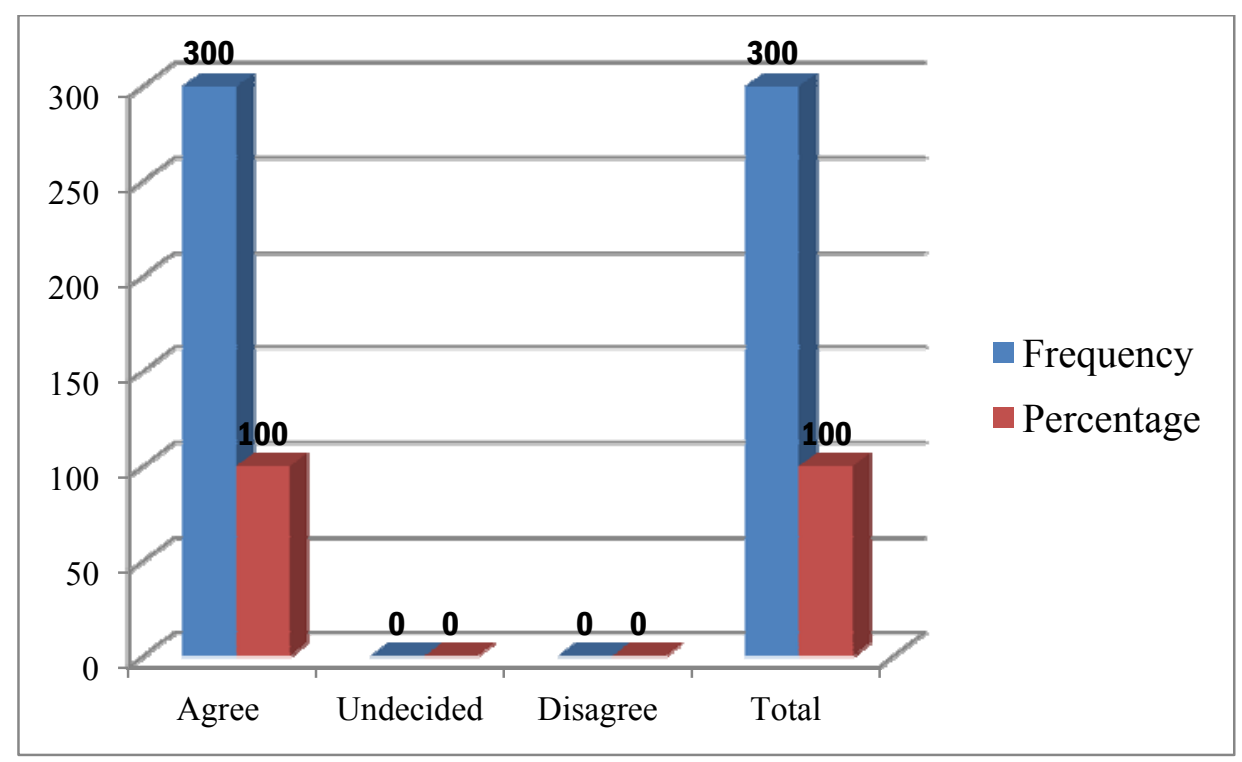

Source: Field Survey May, 2015

The study posed this question in recognition of the fact that one major challenge to manpower planning is disagreement among management team as whether to adopt manpower planning or not. The above bar chart shows that 300 or 100.0 percent of the respondents agreed that there is need for manpower planning and development in an organization. Thus, with the preponderance of 300 or 100.0 percent who agreed, we can therefore conclude that respondents were aware of the imperatives of manpower planning and development in an organization. 
Bar Chart 4: Respondents' Views on whether there is adequate and functional arrangement for replacement of disengaged, resigned or retired personnel in the Lagos state service

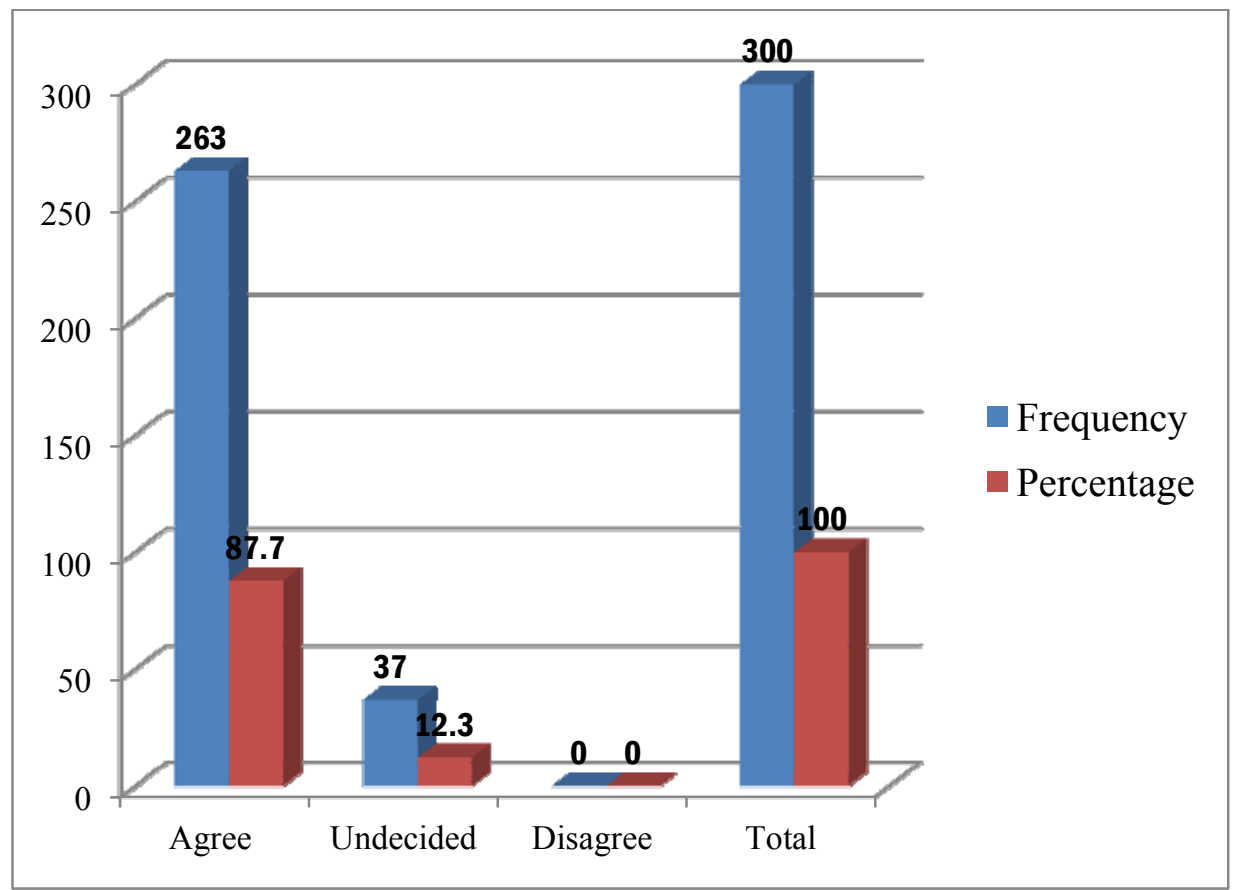

Source: Field Survey May, 2015

An analysis of the above bar chart reveals that 263 or 87.7 percent of the respondents agreed that there is adequate and functional arrangement for replacement of disengaged, resigned or retired personnel in the service while 37 or 12.3 percent were undecided. Thus, with overwhelming majority 87.7 percent who agreed, we can conclude that Lagos state civil has adequate and functional arrangement for replacement of disengaged, resigned or retired personnel. 
The Effect of Manpower Planning \& Development in Lagos State Civil Service Performance 99

Bar Chart 5: Represents the opinion of respondents on whether ministries adheres to merit as guiding principles in selecting officers for training and development

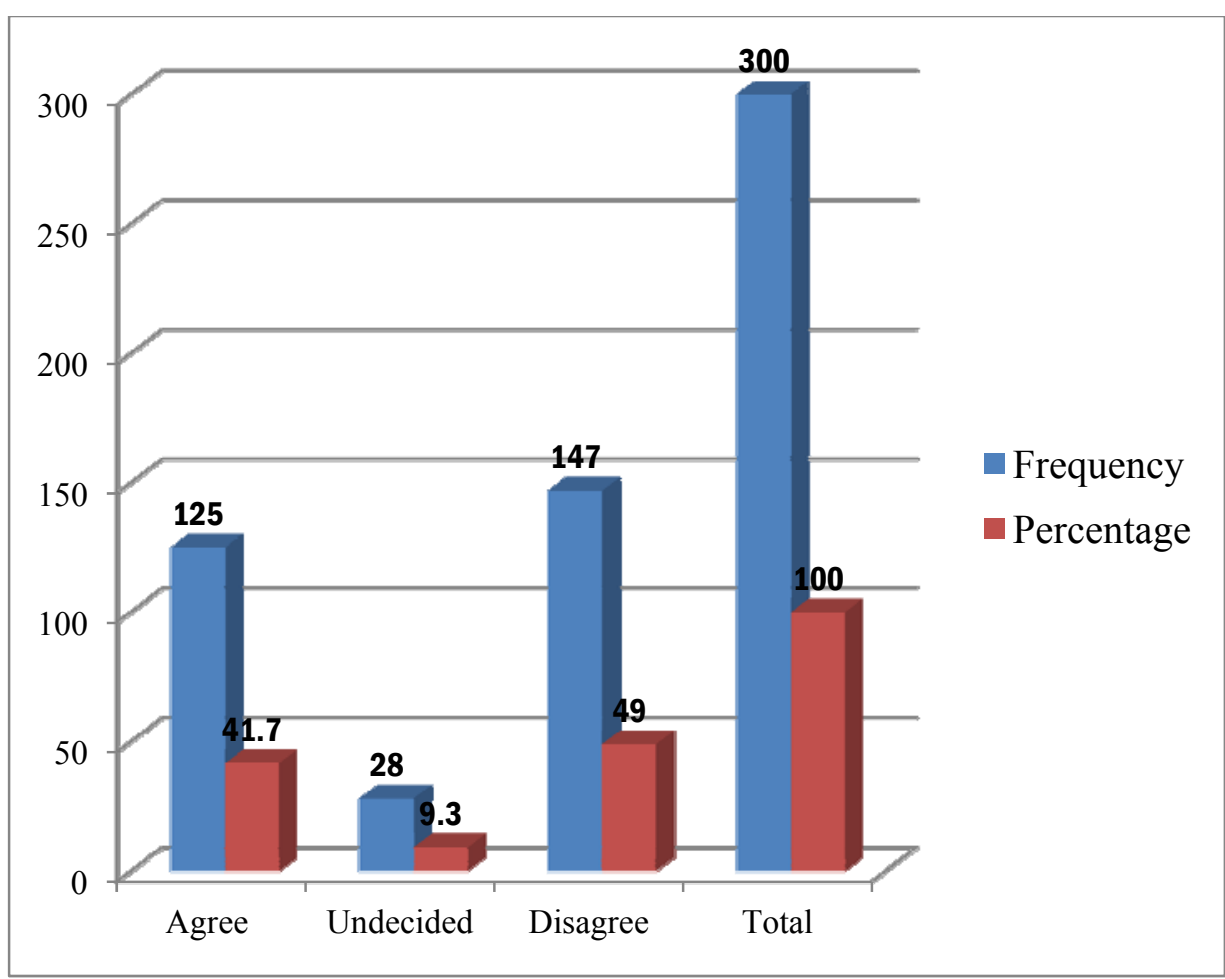

Source: Field Survey May, 2015

An analysis of the above bar chart reveals that 125 or 41.7 percent of the respondents agreed while 147 or 49.0 percent disagreed with the statement. Another 28 or 9.3 percent were undecided. Although, 147 or 49.1 percent of the respondents disagreed, the percent is not enough to conclude that Lagos State civil service does not adhere to merit as guiding principles in selecting officers for training and development. 
Bar Chart 6: Represent views of respondents on whether the nature of manpower planning and development curriculum in the Lagos state civil service is capable of producing an effective workforce.

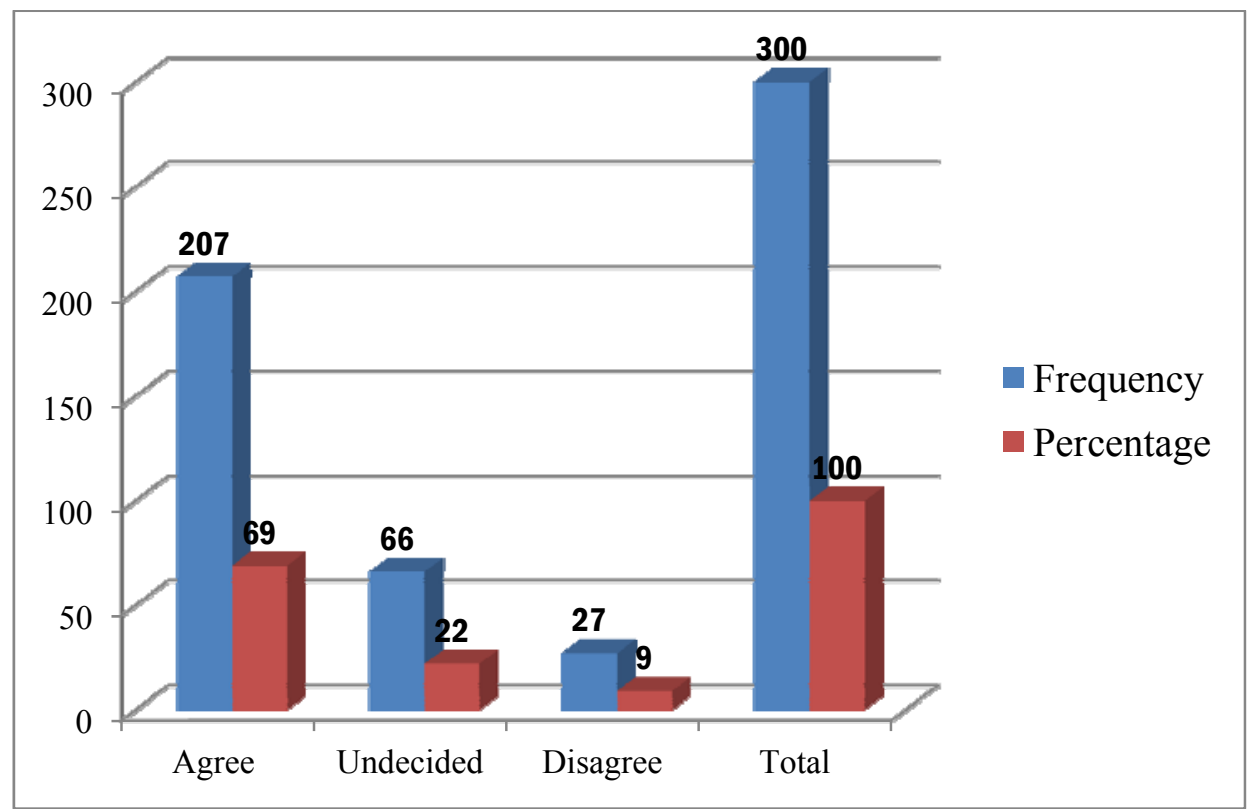

Source: Field Survey May, 2015

A critical analysis of the above bar chart indicate that 207 or 69.0 percent of the respondents agreed that the nature of manpower planning and development curriculum in the Lagos state civil service is capable of producing an effective workforce, while 27 or 9.0 percent disagreed with 66 or 22.0 percent undecided. Thus, with majority 69.0 percent who agreed with the proposition, we conclude that the nature of manpower planning and development curriculum in the Lagos state civil service is capable of producing an effective workforce. 
Bar Chart 7: Respondents' views on whether the nature of manpower planning and manpower development curriculum has a positive effect on Lagos civil service performance

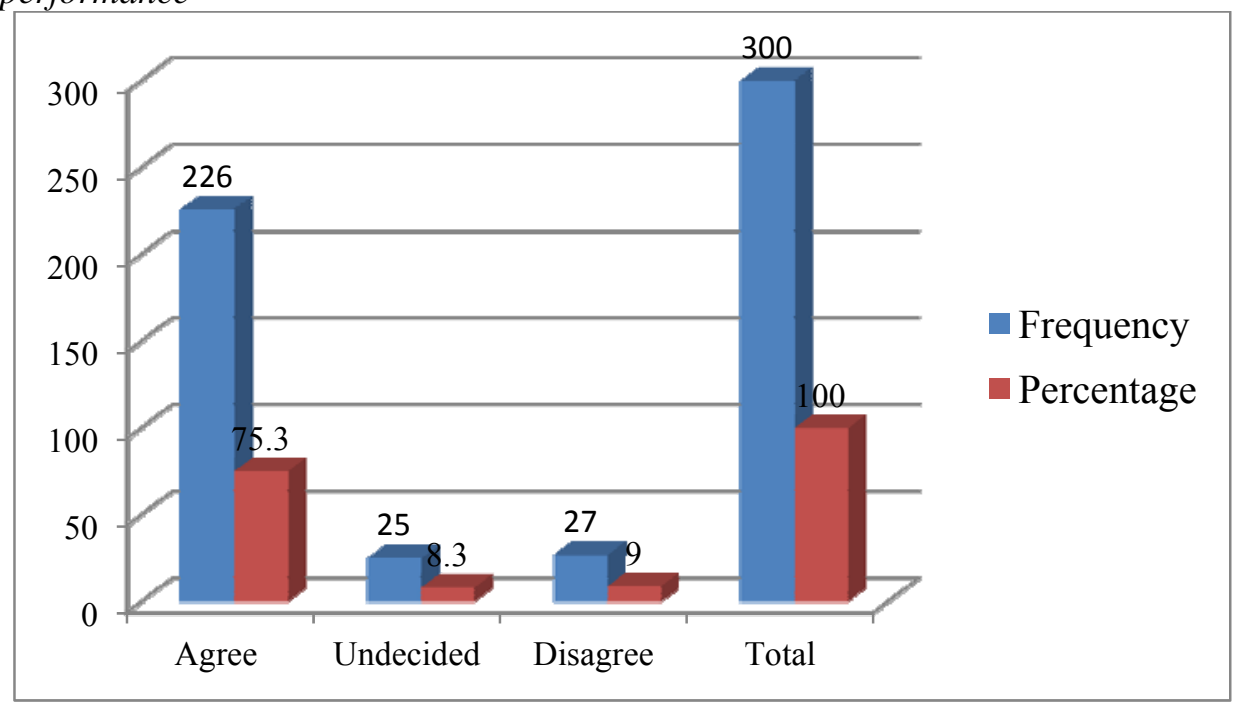

Source: Field Survey May, 2015

The study poses this question to ascertain whether the nature of manpower planning and manpower development curriculum in Lagos civil service has a positive or negative effect on Lagos state performance. It is also to validate or invalidate the first research hypothesis. A cursory look at the above bar chart indicate that 226 or 75.3 percent of the respondents agreed that there is a significant relationship between the nature of manpower planning and manpower development curriculum in Lagos state civil service while 27 or 9.0 percent disagreed with the proposition. Another 25 or 8.3 percent were undecided. Thus, with the majority 75.3 percent who agreed with the proposition, we can therefore conclude that the nature of manpower planning and manpower development curriculum in Lagos civil service has a positive effect on organizational performance. This result invalidates the first null hypothesis of the study. 
Bar Chart 8: Views of respondents on whether Lagos state civil service manpower planning and development is strategic in nature

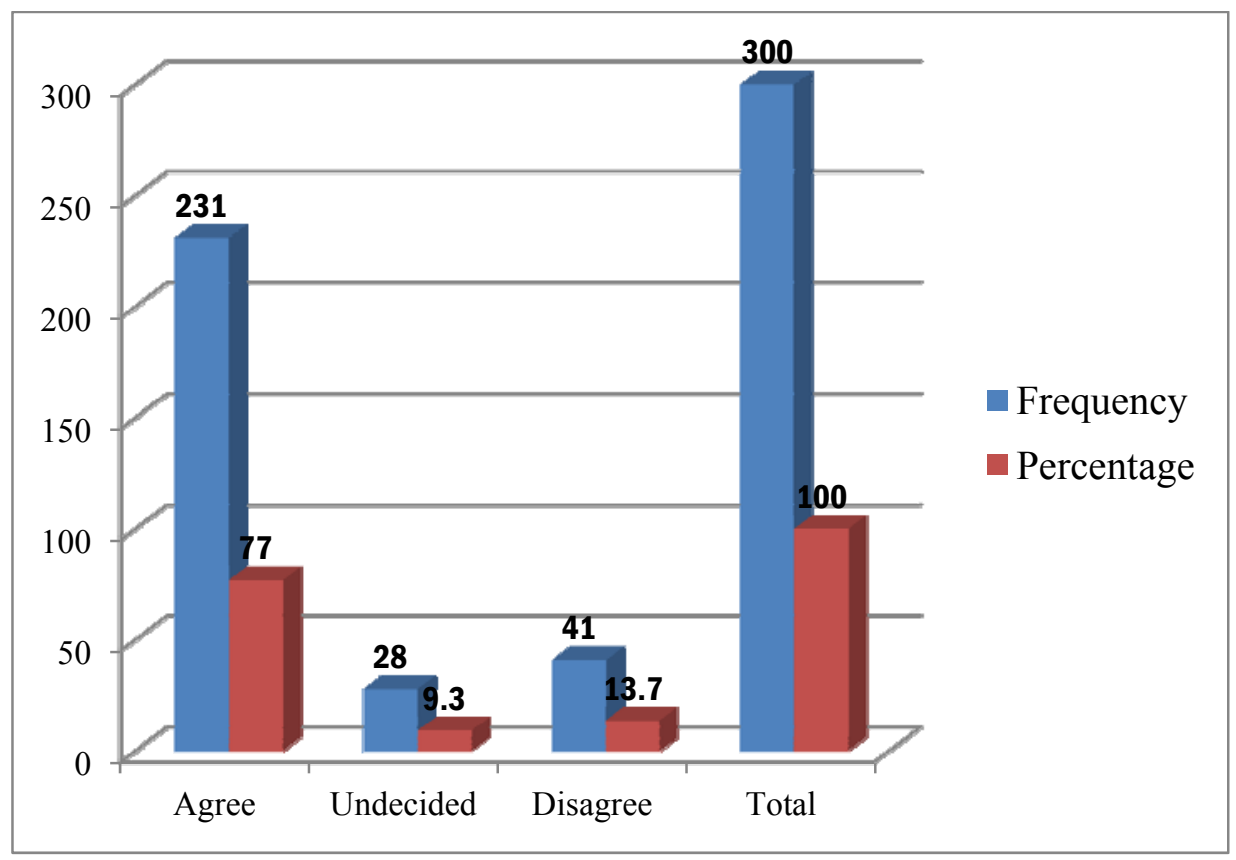

Source: Field Survey May, 2015

An analysis of the above histogram shows that 231 or 77.0 percent of the respondents agreed that the Lagos state civil service manpower planning and development is strategic in nature while 40 or 13.3 percent had a contrary views with another 29 or 9.7 percent being undecided. Thus with majority 77.0 percent who agreed we conclude that manpower and development in the Lagos state civil service is strategic in nature. 
Bar Chart 9: The study queried respondents whether manpower planning and development enhances employees' efficiency and effectiveness

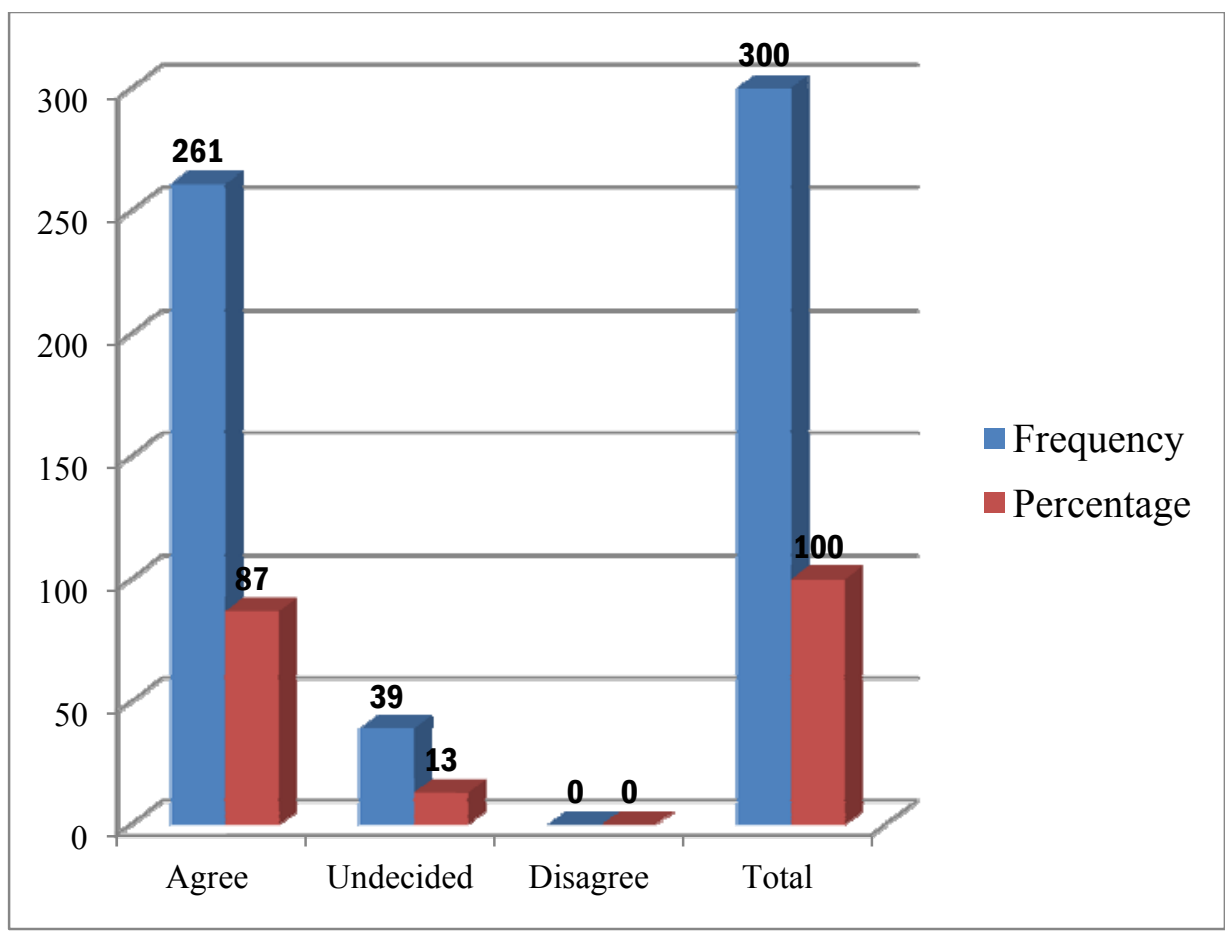

Source: Field Survey May, 2015

The bar chart computation above indicates that 261 or 87.0 percent of the respondents agreed that manpower planning and development enhances organizational efficiency and effectiveness while 39 or 13.0 percent were undecided. With overwhelming majority 87.0 percent who agreed with the proposition, we can therefore, conclude that manpower planning and development enhances organizational efficiency and effectiveness. 
Bar Chart 10: Recognizing the importance of training and development of employees, the study further seek to know if present training and development curriculum in the Lagos state civil service / training institutions is capable of producing an effective workforce

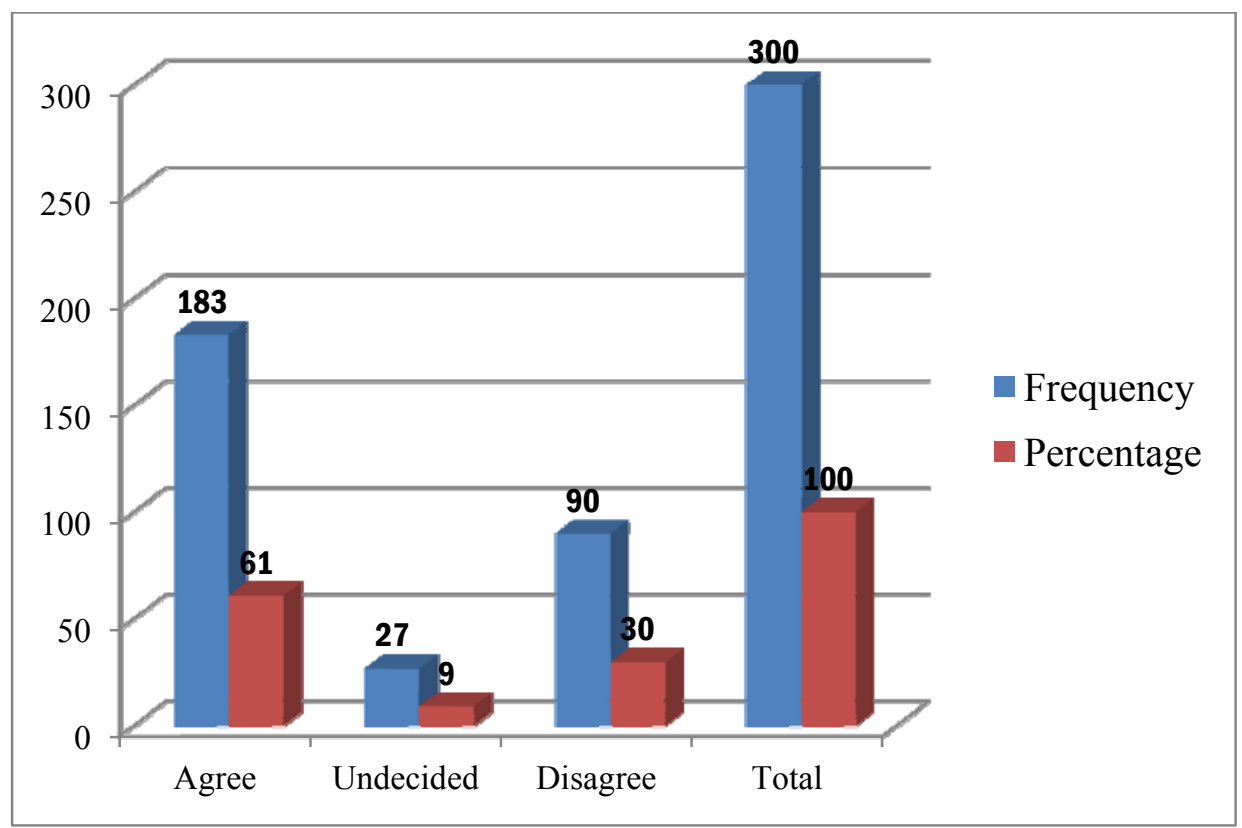

Source: Field Survey May, 2015

A look at the above bar chart reveals that majority of the respondents 183 or 61.0 percent were of the opinion that the present training and development curriculum in the Lagos state civil service/training institutions is capable of producing an effective workforce while only 90 or 30 percent disagreed. However, 27 or 9.0 percent were undecided. With majority 61.0 percent who agreed we conclude that the present training and development curriculum in the Lagos state civil service / training institutions is capable of producing an effective workforce. 
Bar Chart 11: Manpower planning and development helps in energizing workers service delivery

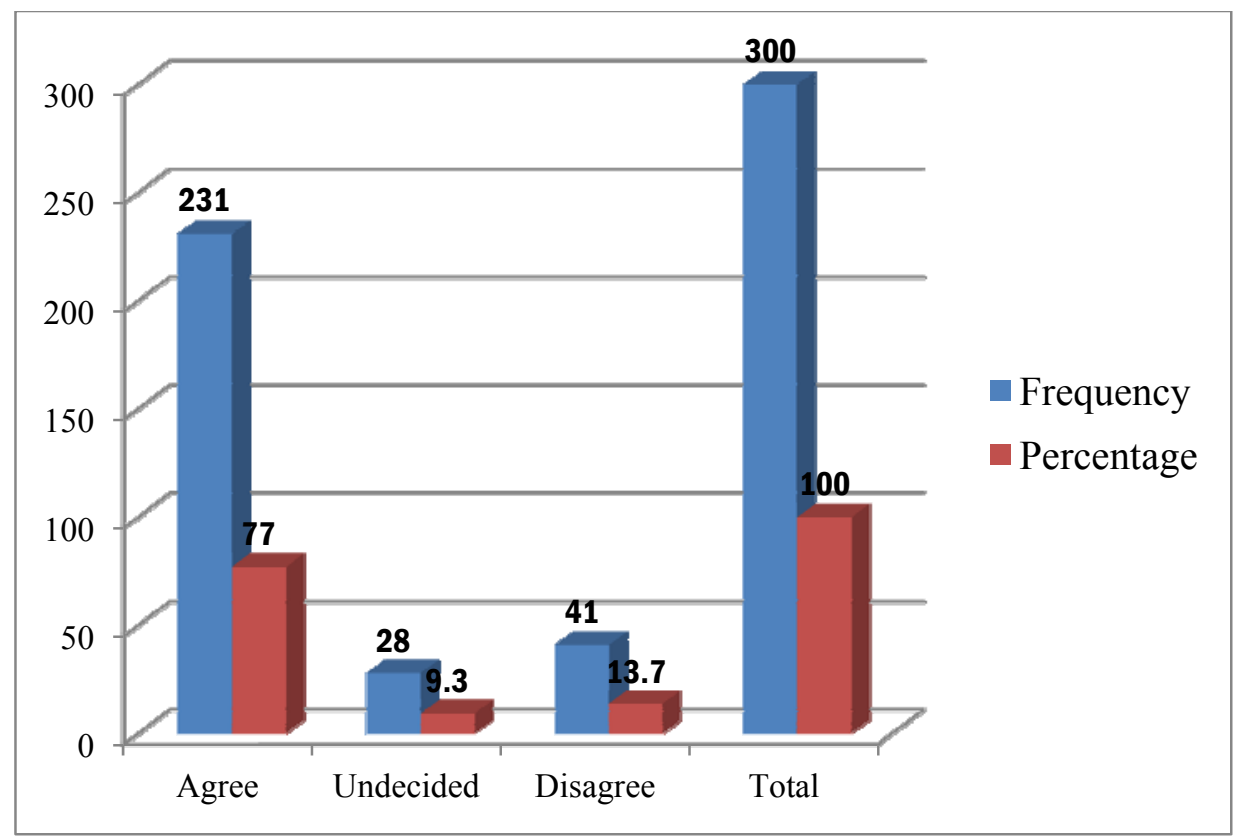

Source: Field Survey May, 2015

The researchers pose this question because manpower planning and development has a synergy with service delivery. The computation in the above bar chart shows that overwhelming majority 231 or 77.0 percent agreed that manpower planning and development helps in energizing workers service delivery while 41 or 13.7 percent disagreed and another 28 or 9.3 percent were undecided. Thus, we conclude that manpower planning and development helps in energizing workers service delivery. 
Bar Chart 12: Portray respondents' views on whether manpower planning and development has a positive effect on Lagos state civil service performance

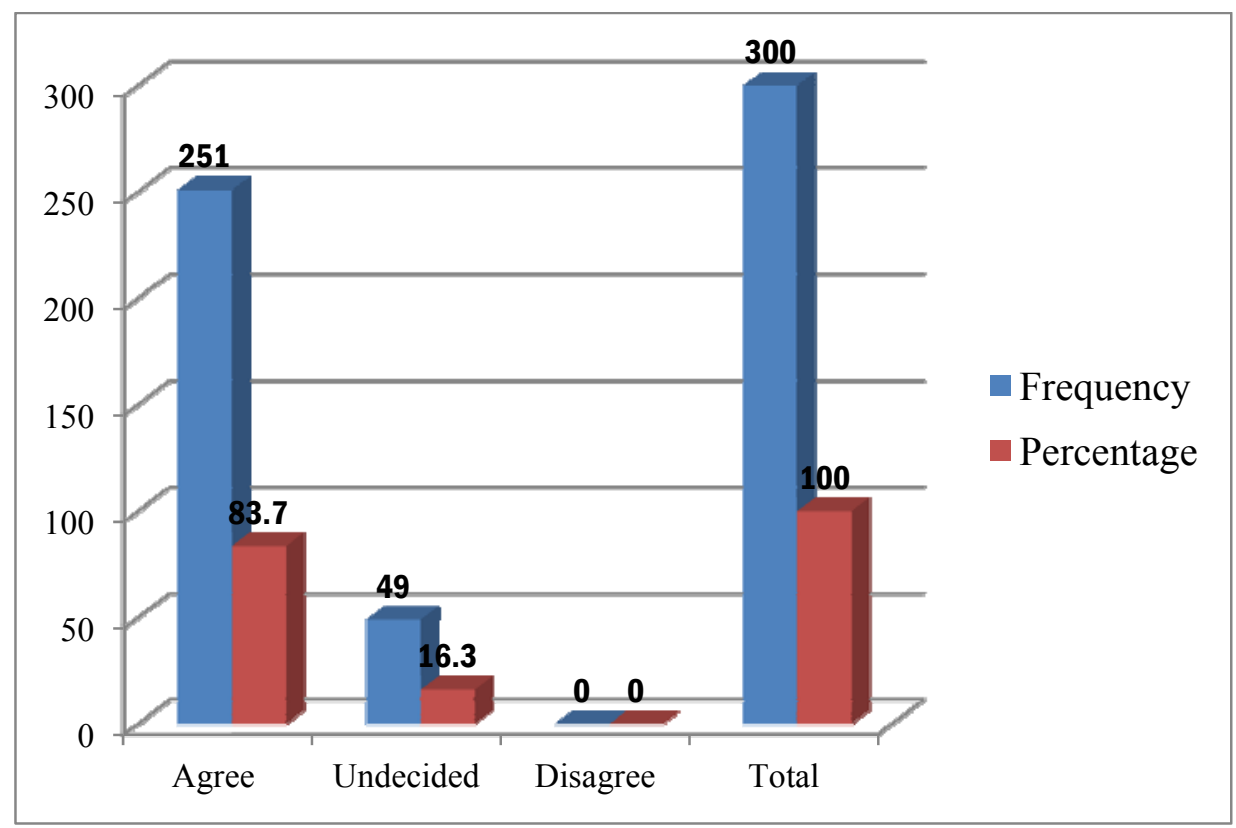

Source: Field Survey May, 2015

The study poses this question to ascertain whether manpower planning and development has a positive or negative effect and organizational performance. It is also to validate or invalidate the second research hypothesis. From the bar chart above, overwhelming majority 251 or 83.7 percent were of the respondents shared the view that manpower planning and manpower development in Lagos state civil service has a positive effect on organizational performance. However, only 49 or 16.3 percent of the respondents were undecided. Thus, we can therefore conclude that manpower planning and manpower development has a positive effect on organizational performance in Lagos civil service. This result invalidates the second null hypothesis. 
Bar Chart 13: In a follow up question, the study asked respondents the number of training and development courses sponsored by government which they attended since joining the Lagos State civil service

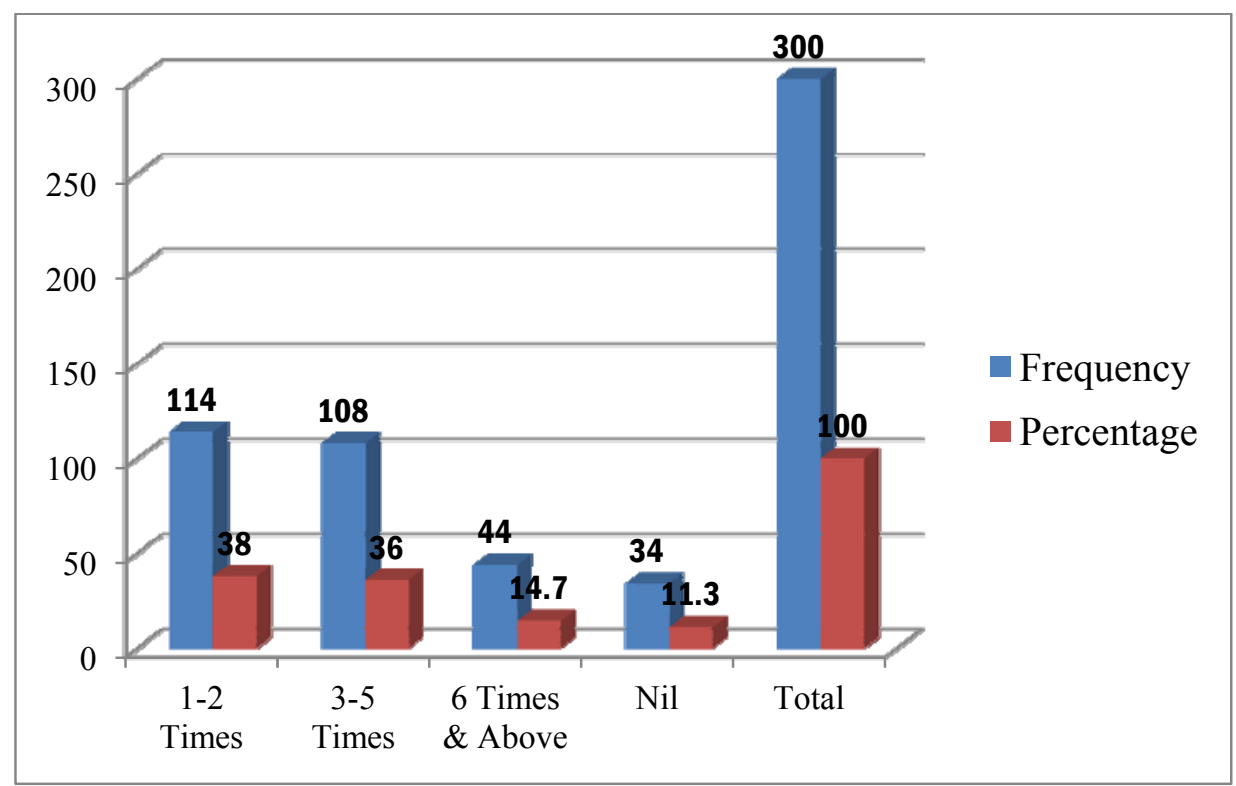

Source: Field Survey May, 2015

We asked this question bearing in mind that training and development in Nigerian civil service is among motivational packages as it sometimes comes with promotion. An analysis of the above bar chart shows that 114 or 38 percent had training and development between once and twice, three or five times attracted 108 or 36 percent while six times and above attracted 44 or 14.7 percent. However, 34 or 11.3 percent were of the opinion that they have never attended any training and development programme since joining the service. Thus, we conclude that overwhelming majority 88.7 percent of the polled respondents have attended one form of training and development programme or other. This result has a positive implication on the Lagos State civil service performance, efficiency and effectiveness. 


\section{Hypothesis One}

$\mathbf{H}_{0}$ : The nature of manpower planning and development curriculum in Lagos state civil service has a negative effect on organizational performance.

\begin{tabular}{|c|c|c|c|c|c|c|c|}
\hline Variable & $\mathbf{N}$ & SUM & r-cal & $\begin{array}{l}\text { P. } \\
\text { value }\end{array}$ & Df & $\begin{array}{l}\text { r-task } \\
\text { value }\end{array}$ & Decision \\
\hline $\begin{array}{l}\text { Nature of } \\
\text { manpower } \\
\text { planning and } \\
\text { development } \\
\text { curriculum (X) }\end{array}$ & 3 & $\begin{array}{l}X: 300 \\
X^{2}: 30744 \\
X Y: 31692\end{array}$ & 0.8427 & 0.05 & 3 & 0.878 & \\
\hline $\begin{array}{l}\text { Organizational } \\
\text { performance }(\mathrm{Y})\end{array}$ & 3 & $\begin{array}{l}Y: 300 \\
Y^{2}: 35418\end{array}$ & & & & & \\
\hline & & & & & & & Rejected \\
\hline
\end{tabular}

\section{Result}

$\mathrm{H}_{0}$ is rejected. This implies that the nature of manpower planning and development curriculum in Lagos state civil service has a positive effect on organizational performance.

\section{Decision}

From the above hypothesis tested, this shows that there is strong positive relationship between the nature of manpower planning and development curriculum in Lagos state civil service performance.

\section{Hypothesis Two}

$\mathrm{H}_{0}$ : Manpower planning and development in the Lagos state civil service has a negative effect on the attainment of Lagos state objective. 
Table 1: Manpower planning and development and attainment of Lagos state objective

\begin{tabular}{|c|c|c|c|c|c|c|c|}
\hline Variable & $\mathbf{N}$ & SUM & r-cal & $\begin{array}{l}\text { P- } \\
\text { value }\end{array}$ & Df & $\begin{array}{l}\text { r-task } \\
\text { value }\end{array}$ & Decision \\
\hline $\begin{array}{l}\text { Manpower } \\
\text { planning and } \\
\text { development in } \\
\text { the Lagos state } \\
\text { civil service }(X)\end{array}$ & 3 & $\begin{array}{l}X: 300 \\
X^{2}: 32648 \\
X Y: 33598\end{array}$ & 0.8597 & \multirow[t]{2}{*}{0.05} & \multirow[t]{2}{*}{3} & \multirow[t]{2}{*}{0.878} & \\
\hline $\begin{array}{l}\text { Attainment of } \\
\text { Lagos state } \\
\text { objective }(\mathrm{Y})\end{array}$ & 3 & $\begin{array}{l}Y: 300 \\
Y^{2}: 36614\end{array}$ & & & & & \\
\hline & & & & & & & Rejected \\
\hline
\end{tabular}

\section{Result}

$\mathrm{H}_{\mathrm{o}}$ is rejected. This implies that the Manpower planning and development in the Lagos state civil service has a positive effect on the attainment of Lagos state objective.

\section{Decision}

From the above hypothesis tested, this shows that there is strong positive relationship between the manpower planning and development in the Lagos state civil service and the attainment of Lagos state objective.

\section{Discussion of Findings}

In view of research questions and the subsequent testing of the two stated hypotheses, the study has revealed that the respondents were all aware of the importance of manpower planning and development in an organization. This is supported by Oguniyi (1992) who argued that manpower planning and development is essential for organizational survival, growth and prosperity. Overwhelming majority 87.7 percent agreed that Lagos State civil has adequate and functional arrangement for replacement of disengaged, resigned or retired personnel. However, 49.1 percent of the respondents disagreed that Lagos state civil service adhere to merit as guiding principles in selecting officers for training and development. Although, majority 49 percent of respondents 
were of the view that Lagos state civil service do not adhere to merit as guiding principles in selecting officers for training and development, indeed 49.1 percent is insignificant to draw conclusion on the proposition. However, 77.0 percent shared the view that Lagos state civil service manpower planning and development is strategic in nature. The study also shows that 0.8427 tend to agree that there is strong positive degree of association between manpower planning and development curriculum in the Lagos state civil service which has become indispensability and capable of producing an effective workforce in the state.

The following deductions can be made with regard to the effect of manpower planning and development on organizational performance in Lagos State civil service. The study established that overwhelming majority 87.0 percent were of the opinion that manpower planning and development enhances organizational efficiency and effectiveness. This is in line with the findings of Subraanian, Shamsudin \& Ibrahim (2011) that manpower planning and development could influence organizational performance because employees skills, knowledge and abilities can be enhanced and be up to date Yet, majority 61 percent of the polled respondents agreed that the present training and development curriculum in the Lagos state civil service/training institutions is capable of producing an effective workforce.

The findings show that manpower planning and development helps in energizing workers service delivery. Overwhelming majority 84.3 percent of the respondents confirmed this assertion. The study also indicates that majority 88.7 percent of the polled respondents have attended one form of training and development programme or the other. This result has a positive implication on the Lagos state civil service performance, efficiency and effectiveness. This is in line with the position of Adeleke in (Igbokwe-Ibeto, 2012) that training and development is the means and process of imparting special skills which equip individuals to perform specific jobs. Although, it is supplement to education, it can be acquired concurrently.

Subsequent testing of the two stated hypotheses shows that the nature of manpower planning and development curriculum in Lagos state civil service has a strong positive effect on organizational performance. This is confirmed by Pearson product moment correlation (PPMC) results. The result is in line with Abeeha \& Bariha (2012); Armstrong (2010) that manpower planning and development curriculum is very necessary for an organization. This is also supported by Dimba (2010) who admonished that bad 
The Effect of Manpower Planning \& Development in Lagos State Civil Service Performance 111

manpower planning and development design is nothing but the loss of time and money. This result invalidates the first null hypothesis of the study.

The result of the second hypothesis shows that manpower planning and development has a strong positive effect on the attainment of Lagos state objective. This is confirmed by Pearson product moment correlation (PPMC) results. It also invalidates the second null hypothesis of the study. This result is in line with research findings of Apospori, Nikandrou, Brewster \& Papalexandris (2008) that found a significant link between manpower training and development and organizational performance. This is also righty supported by Omotoso (1992) who persuasively argued that manpower planning and development is a key to nation's survival, prosperity, and examines future economic and social development.

\section{Recommendations}

Relative to the findings of this study, the following is recommended: Lagos state civil service should improve on the current manpower planning strategy and continue to update its manpower development curriculum in line with the global best practices.

To achieve better performance, employees' commitment and attitude to work, Lagos state civil service should imbibe the prescripts of NPM that goals and targets should be defined and measurable as indicators of organizational performance. Yet, manpower planning and development curriculum should be based on organizational needs while officers selected for training and development should be based on merit and training and development needs.

Given the pivotal role that technology plays in the $21^{\text {st }}$ century, the civil service should avail itself of the windows of opportunities that information technology provides in its drive to further enhance employees' skills, knowledge and abilities that will invariably improve organizational performance.

Government at all levels should ensure that there is a bearing between manpower planning and development with national/state objectives and policy because this is the only way government could have a poll of competent employees' to drive and implement its developmental policies and programmes. 


\section{Conclusion}

With New Public Management theory underlying the foundation for this study, it is posited that for government to operate the most efficient and effective administrative organization that would be beneficial to all, her manpower planning and manpower development curriculum should be meticulously designed and implemented. It should also be capable of adhering to manpower planning and development policies and programmes as this would in turn help government to achieve the goals of governance and administration. It was concluded from the findings of this study that Lagos State civil service manpower planning and development is averagely good and its training and development curriculum is capable of producing an efficient workforce and, in turn, have a positive implication for Lagos State civil service performance.

\section{List of References}

- Abeeha, B \& Bariha, B. 2012, Effects of employees training on the organizational competitive advantage: empirical study of private sector of Islamabad, Far East Journal of Psychology and Business, 6(1):265-298

- Adamolekun, L. 2009, Public administration: Nigeria and comparative perspective, London: Longmans

- $\quad$ Ake, C. 2001, Democracy and development in Africa, Ibadan: Spectrum Books Limited.

- Apospori, E., Nikandrou, I., Brewster, C. \& Papalexandris, N. (2008), HRM and organizational performance in Northern and Southern Europe, International Journal of Human Resource Studies, 19(7):1187-1207

- Armstrong, M. 2010, Armstrong's essential human resource management practices: a guide to people management, London: Kogan Page

- Asika, N. 2006, Research methodology in the behavioural sciences, Lagos: Longman Nigeria PlC

- Babbie, E \& Mouton, J. 2001, The practice of social research, Cape Town: Oxford University Press 
The Effect of Manpower Planning \& Development in Lagos State Civil Service Performance 113

- Best, W. \& Kahn, V. 2006, Research in education, Essex: Person Education.

- Boxall, P. \& Purcell, J. 2003, Strategy and human resource management, New York: Palgrave Macmillan

- Byars, L.L. and Rue, L.W. 2006, Human resource management, New York: The McGraw-Hill.

- Chalofsky, N.E, \& Reinhart, C. 2008, Effective human resource development, California: Jossey Bass Inc.

- Chandan, J.S. 2005, Management theory and practice, New Delhi: Vikas Publishing House PVT Ltd

- Cole, G.A. 2002, Personnel and human resource management, Indian: Prentice Hall

- Dauda, S. 2003, The crisis of development in Africa: the democratic imperatives, Journal of Development Studies, 1(4):84-87

- Dibie, R. \& Dibie, J. 2014, Dichotomy of capacity building and youth unemployment in Ethiopia, Public Service Delivery and Performance Review, 2(3):25-76

- Dimba, B.A. 2010, Strategic human resource management practice: effects on Performance, African Journal of Economic and Management Studies, 1(2):128-137

- Drucker, P.F. 1999, Management challenges for the $21^{\text {st }}$ century. New York: Harper Business.

- Ebegbuna, P.O 1992, "Staff inspection and manpower budgeting" in A.D. Yahaya \& I. C. Akinyele (Eds.), New Trends in Personnel Management. A Book of Reading, Badagry: Administrative Staff College

- Ekpo, A.H. 2009, "Manpower development in Nigeria". In S.C Ogbuagu (Ed.), Strategy for National Development in Nigeria. Calabar: University of Calabar Press

- Eneanya, A.N. 2009, Principles and practice of public personnel administration in Nigeria Lagos: Concept Publications Limited

- Federal government of Nigeria. 1998, National policy on education. Lagos: Federal Government Press

- Grabowski, R., \& Shields, M. 2006, Development economics. New York: Blackwell Publishers Incorporation

- Hood, C.C. 1996. Exploring variations in public management reforms of the 1980s, in H.A Bekke, J.L Pery \& T.A Toonen (Eds.), Civil Service System in Comparative Perspective, Bloomington: Indiana University Press 
- Hood, C. 1991. A public management for all seasons, Public Administration (69) Spring

- Igbokwe-Ibeto, C.J \& Osawe, C.O. 2014, Gaining competitive advantage through effective staff development framework, Journal of Policy and Development Studies, 8(3):17-28

- Igbokwe-Ibeto, C.J. 2012, Delivering efficient public service in Nigeria through better performance management frameworks, International Journal of Social Sciences and Humanities Review, 3(I):182-195

- Jones, G.R., George, J.M., \& Hill, C.W.L. 2000, Contemporary management, New York, Irwin and McGraw Hills

- Koontz, H., O'Donnel, C, \& Weihrich, H. 2008, Management, Japan: McGraw Hill Publishing Company

- Lawal, M.M. 2006, Manpower management: a hand book for personnel managers and students of administration, Abuja: Roots Books and Journals Nigeria Limited

- Lagos State Government. 2014, Lagos bureau of statistics

- Mapira, N., Katsuro, P., Chazuza, T., Mlingwa, M.M., Togarepi, M., Mutambatuwisi, F., Nhimba, N.K., Umera, T \& Machigere, T. 2013, The importance of establishing job analysis exercise in an organisation: a case study of bread manufacturing companies in Zimbabwe, Australian Journal of Business and Management Research, 2(11):35-42

- Muchinsky, P.M. 2000, Psychology applied to work, New York: Wadsworth/Thomson Learning.

- National Population Commission 2013, Nigeria's population estimate, Abuja: Government Printer.

- Nongo, S. 2005, Fundamental of management, Makurdi: Aboki Publishing Company

- Omodia, S. 2004, The family as a vehicle for sustainable democracy in Nigeria, Journal of Farm Development, 1(1):83

- Omodia, S. 2005, Poverty alleviation in a deregulated economy, challenges and prospects for sustainable democracy in Nigeria. Journal of Administration, 2(1):118 - 124

- Omodia, S. M. 2009, Manpower development in Nigeria: conceptual and methodological perspectives, Journal of Social Sciences, 18(2):113-117

- Oguniyi, O. 1992, "Manpower planning: issues and problems in Nigeria" in A.D. Yahaya \& I. C. Akinyele (Eds.), New Trends in Personnel Management. A Book of Reading, Badagry: Administrative Staff College 
The Effect of Manpower Planning \& Development in Lagos State Civil Service Performance 115

- Olu-Adeyemi, L. 2009, "Public administration reform in Nigeria", in R.F Ola \& D.A Tonwe (Eds.), Nigerian Public Administration, Lagos: Amfitop Books

- Omotade, D. 1992, "Formulation and implications of personnel policy in the civil service" in A.D. Yahaya Z \& I. C. Akinyele (Eds.), New Trends in Personnel Management. A Book of Reading, Badagry: Administrative Staff College

- Pollitt, C. 1996, Managerialism and public services, the Anglo-American experiences, Oxford: Basil Blackwell

- Robb, C.M. 2002, Can the poor influence policy? New York: World Bank

- Schular, R.S. 1998. Human resource management. positioning for the 21st century, St Paul: West Publishing.

- Subraanian, C., Shamsudin F.M., \& Ibrahim, H. 2011, Linking human resource practice and organizational performance: evidence from small and medium organizations in Malaysia, Journal of Pengurusan, 32, 27-37

- Ulrich, D. 2007, Measuring human resources: an overview of practice and a prescription for results, Human Resources Management, 36, 303-20

- United Nations Development Programme, 2003, Human development report, UNDP, New York: Oxford University Press

- Walker, P. 2007, Develop an effective employer brand, People Management, $18^{\text {th }}$ October

- World Bank, 2012, Ethiopia protection of basic services phase 2 project. Washington, D.C: World Bank

- World Bank, 2009, World development report, New York: Oxford University Press.

- Wright, P M., McCormick, B., Sherman, W. \& McMahan, G. 1999, The role of human resource practices in petro-chemical refinery performance, International Journal of Human Resource Management, 10(4):551-571

- Yalokwu, P.O. 2000, Management: concept and techniques, Lagos: Peak Publishers

- Yamane, T. 1967, Statistics: an introductory analysis. New Delhi: Yani Publisher 


\section{AUTHORS' CONTACT:}

IGBOKWE-IBETO, Chinyeaka J. OSADEKE, Kehinde 0

Dept of Public Administration Faculty of Mgt Sciences Nnamdi Azikiwe University, Awka, Nigeria

Email: ugochinyerecj@yahoo.co.uk
Dept of Political Science \&

Public Administration

Babcock University,

Ilishan-Remo

ANAZOD0, Rosemary 0

Dept of Public Admin

Faculty of Mgt Sciences

Nnamdi Azikiwe University

Awka, Nigeria 